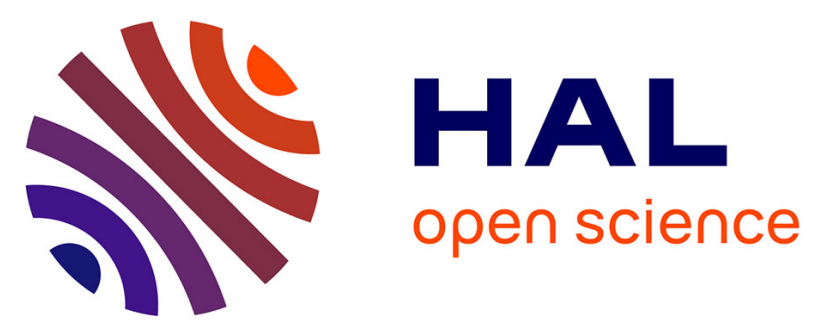

\title{
High feather mercury concentrations in the wandering albatross are related to sex, breeding status and trophic ecology with no demographic consequences
}

Paco Bustamante, Alice Carravieri, Aurélie Goutte, Christophe Barbraud, Karine Delord, Olivier Chastel, Henri Weimerskirch, Yves Cherel

\section{To cite this version:}

Paco Bustamante, Alice Carravieri, Aurélie Goutte, Christophe Barbraud, Karine Delord, et al.. High feather mercury concentrations in the wandering albatross are related to sex, breeding status and trophic ecology with no demographic consequences. Environmental Research, 2016, 144, pp.1-10. 10.1016/j.envres.2015.10.024 . hal-01223563

\section{HAL Id: hal-01223563 \\ https://hal.science/hal-01223563}

Submitted on 2 Nov 2015

HAL is a multi-disciplinary open access archive for the deposit and dissemination of scientific research documents, whether they are published or not. The documents may come from teaching and research institutions in France or abroad, or from public or private research centers.
L'archive ouverte pluridisciplinaire HAL, est destinée au dépôt et à la diffusion de documents scientifiques de niveau recherche, publiés ou non, émanant des établissements d'enseignement et de recherche français ou étrangers, des laboratoires publics ou privés. 
High feather mercury concentrations in the wandering albatross are related to sex, breeding status and trophic ecology with no demographic consequences

Paco Bustamante ${ }^{\mathrm{a}^{\mathrm{a}}}$, Alice Carravieri ${ }^{\mathrm{a}, \mathrm{b}}$, Aurélie Goutte ${ }^{\mathrm{b}, \mathrm{c}}$, Christophe Barbraud ${ }^{\mathrm{b}}$, Karine Delord ${ }^{\mathrm{b}}$, Olivier Chastel ${ }^{\mathrm{b}}$, Henri Weimerskirch ${ }^{\mathrm{b}}$, Yves Cherel ${ }^{\mathrm{b}}$

${ }^{\text {a }}$ Littoral Environnement et Sociétés (LIENSs), UMR 7266 CNRS-Université de la Rochelle, 2 rue Olympe de Gouges, 17000 La Rochelle, France

b Centre d'Etudes Biologiques de Chizé (CEBC), UMR 7372 du Centre National de la Recherche Scientifique-Université de La Rochelle, 79360 Villiers-en-Bois, France

${ }^{\text {c }}$ École Pratique des Hautes Études (EPHE), SPL, UPMC Université Paris 06, UMR 7619 METIS, F-75005, 4 place Jussieu, Paris, France

*corresponding author: Paco Bustamante

UMR LIENSs

2 rue Olympe de Gouges

17000 La Rochelle

Tel : +33(0)546507625

E-mail : pbustama@univ-lr.fr 
Abstract: $\mathrm{Hg}$ can affect physiology of seabirds and ultimately their demography, particularly if they are top consumers. In the present study, body feathers of $>200$ wandering albatrosses from Possession Island in the Crozet archipelago were used to explore the potential demographic effects of the long-term exposure to $\mathrm{Hg}$ on an apex predator. Variations of $\mathrm{Hg}$ with sex, age class, foraging habitat (inferred from $\delta^{13} \mathrm{C}$ values), and feeding habits (inferred from $\delta^{15} \mathrm{~N}$ values) were examined as well as the influence of $\mathrm{Hg}$ on current breeding output, long-term fecundity and survival. Wandering albatrosses displayed among the highest $\mathrm{Hg}$ feather concentrations reported for seabirds, ranging from 5.9 to $95 \mu \mathrm{g} \mathrm{g}^{-1}$, as a consequence of their high trophic position ( $\delta^{15} \mathrm{~N}$ values). These concentrations fall within the same range of those of other wandering albatross populations from subantarctic sites, suggesting that this species has similar exposure to $\mathrm{Hg}$ all around the Southern Ocean. In both immature and adult albatrosses, females had higher $\mathrm{Hg}$ concentrations than males (28 vs $20 \mu \mathrm{g} \mathrm{g}^{-1} \mathrm{dw}$ on average, respectively), probably as a consequence of females foraging at lower latitudes than males $\left(\delta^{13} \mathrm{C}\right.$ values). $\mathrm{Hg}$ concentrations were higher in immature than in adult birds, and they remained fairly constant across a wide range of ages in adults. Such high levels in immature individuals question (i) the frequency of moult in young birds, (ii) the efficiency of $\mathrm{Hg}$ detoxification processes in immatures compared to adults, and (iii) importantly the potential detrimental effects of $\mathrm{Hg}$ in early life. Despite very high $\mathrm{Hg}$ concentrations in their feathers, neither effects on adults' breeding probability, hatching failure and fledgling failure, nor on adults' survival rate were detected, suggesting that long-term bioaccumulated $\mathrm{Hg}$ was not under a chemical form leading to deleterious effects on reproductive parameters in adult individuals.

Keywords: Bioaccumulation; Metal; Sex; Age; Immature; Stable isotopes; Southern Ocean 


\section{Highlights:}

Immature albatrosses had higher feather $\mathrm{Hg}$ concentrations than adults

Foraging habitat influenced $\mathrm{Hg}$ bioaccumulation as a result of male and female segregation No carry-over effects were detected on reproductive parameters 


\section{Introduction}

Mercury $(\mathrm{Hg})$ is a non-essential element that bioaccumulates in organisms and biomagnifies through food webs. Both processes are due to the conversion of inorganic Hg into organic forms (mainly methylmercury, $\mathrm{MeHg}$ ) in aquatic ecosystems, $\mathrm{MeHg}$ being highly bioavailable and toxic. As such, $\mathrm{MeHg}$ is harmful to biota, being associated with adverse effects such as neurological, immunological, physiological and reproductive impacts in both humans and wildlife (e.g. Evans et al., 1982; Thompson and Furness, 1989a; Burger and Gochfeld, 1997; Tan et al. 2009). Nonetheless, the natural occurrence of $\mathrm{Hg}$ (Nriagu, 1996) has involved adaptations of predators to the presence of this toxic metal in their environment. This is particularly obvious for many top predators whose high trophic position and long life span lead to important levels of exposure. Most marine top predators feed on fish and cephalopods, which concentrate Hg mainly under MeHg (Bloom 1992; Bustamante et al. 2006). Marine apex predators have thus developed efficient detoxification capacities to support elevated exposure to $\mathrm{MeHg}$ (reviews in Cuvin-Aralar and Furness, 1991; Das et al., 2000). In marine mammals, demethylation of $\mathrm{MeHg}$ in the liver leads to the production of non-toxic granules of tiemannite (Koeman et al., 1973; Martoja and Berry, 1980). The accumulation of tiemannite granules makes the liver the ultimate organ of retention of $\mathrm{Hg}$ (Wagemann et al., 1998; 2000). Since these granules are not excreted (Nigro and Leonzio, 1996), inorganic $\mathrm{Hg}$ is basically stored through the whole life, thus inducing particularly elevated and increasing liver $\mathrm{Hg}$ 
concentrations throughout life, without any apparent toxic effect (Cuvin-Aralar and Furness, 1991).

In aquatic birds, efficiency of $\mathrm{Hg}$ detoxification processes is critical to prevent the toxic effects of $\mathrm{Hg}$, which can affect their breeding, hatching and fledging successes (Tan et al. 2009, Frederick and Jayasena 2010, Tartu et al. 2013, Goutte et al. 2014a,b). As in mammals, demethylation of $\mathrm{Hg}$ in the liver appears to be a significant detoxification mechanism in seabirds (Thompson and Furness 1989b, Thompson et al. 1993). However, birds present another complementary and efficient way to detoxify and excrete $\mathrm{Hg}$ on a regular basis, namely moult. $\mathrm{Hg}$ binds to keratin in the form of $\mathrm{MeHg}$, hence, most feather $\mathrm{Hg}$ is $\mathrm{MeHg}$ (Thompson and Furness, 1989a), thus leading to a direct elimination of the toxic organic form during feather growth and subsequent loss. Feathers are considered as the main route for $\mathrm{Hg}$ excretion in seabirds (Monteiro and Furness 1995), with feather growth contributing to the elimination of $>90 \%$ of the $\mathrm{Hg}$ accumulated since the previous moult (Braune and Gaskin 1987). In some cases, moult of all feathers is synchronous, as in penguins that renew their whole plumage in a few weeks (Brasso et al. 2013, Carravieri et al. 2013, 2014a), but generally moult is sequential and takes many weeks to months to be completed. For example, the wandering albatross Diomedea exulans replaces its feathers slowly and infrequently over several consecutive interbreeding periods (Weimerskirch 1991) and this extreme moulting pattern is believed to contribute significantly to high feather $\mathrm{Hg}$ concentrations in the species (Anderson et al., 2009; Becker et al., 2002). 
The present study adds new information on $\mathrm{Hg}$ exposure, the factors explaining its variations, and its demographic consequences on the wandering albatross breeding at Possession Island in the Crozet archipelago (southern Indian Ocean). There, an exceptional long-term demographic capture-mark-recapture survey (1965-present) allows a robust knowledge of the life history of each individual (Weimerskirch et al., 1997). The wandering albatross was chosen as a model animal because (i) it is an apex predator that occupies the highest trophic position within the diverse community of subantarctic seabirds, being thus submitted to contaminant biomagnification processes (Blévin et al. 2013), (ii) it is a very longlived species (> 50 years) making it a species of particular interest to investigate $\mathrm{Hg}$ bioaccumulation patterns over the long term (Tavares et al. 2013, Carravieri et al. 2014b), and (iii) consequently the species presents consistently high $\mathrm{Hg}$ levels in various tissues, including liver, blood and feathers (Hindell et al., 1999; Stewart et al. 1999, Anderson et al. 2009, Carravieri et al. 2014b,c). The study is a companion work to a broader investigation using the same birds and data set that focused on (i) the complex foraging pattern of wandering albatrosses according to age, sex and breeding status using stable isotopes (Jaeger et al. 2014), (ii) the effect of all these factors and foraging ecology as explanatory variables of blood contaminants ( $\mathrm{Hg}$ and persistent organic pollutants) (Carravieri et al. 2014b), and (iii) the corresponding consequences of blood contamination levels on birds' demography (Goutte et al. 2014b). 
We focused here on $\mathrm{Hg}$ in body feathers to complement the previous investigations on blood, because the two tissues represent short- and long-term exposure to $\mathrm{Hg}$, respectively. Blood $\mathrm{Hg}$ is directly influenced by recent dietary intake, while feathers are representative of $\mathrm{Hg}$ bioaccumulation over the inter-moult period (at least two years for body feathers in the wandering albatross). Our goal was three fold, by increasing order of importance (i) to describe body feather $\mathrm{Hg}$ concentrations in a larger data set of sampled birds $(n>200)$ than in most previous investigations on marine predators, (ii) to quantify the main intrinsic (sex, age and breeding status) and extrinsic (foraging habitat and trophic position) factors contributing to $\mathrm{Hg}$ variation, and (iii) the demographic consequences of feather $\mathrm{Hg}$ levels in terms of current probabilities of breeding success, and of long-term apparent probabilities of adult survival, return to the breeding colony, and breeding, hatching and fledgling successes. We also further investigated the surprising recent finding on a few birds showing that feather $\mathrm{Hg}$ concentrations were higher in young immature wandering albatrosses than in older immatures and adults (Tavares et al., 2013).

\section{Materials and Methods}

\subsection{Study area, species and fieldwork}

Wandering albatrosses nest on subantarctic islands throughout the Southern Ocean. The study was conducted at Possession Island in the Crozet Archipelago $\left(46^{\circ} \mathrm{S}, 52^{\circ} \mathrm{E}\right)$, Southern Indian Ocean, where 300-400 pairs nest each year (Delord et al. 2008). Although the minimal age at first reproduction is five years old, ten years is the mean age of first breeding in this population (Weimerskirch et al. 1997). Wandering albatrosses return to their breeding grounds each year in December and females lay a single egg in late December-early January. Both parents incubate alternatively until hatching in March. Chicks are reared for $\approx 280$ days and 
most young are fledged in November. It was recently demonstrated that up to $6 \%$ of the birds that fledged a chick still breed 2 years in a row, and the species is now considered as a quasibiennial breeding species (Barbraud and Weimerskirch, 2012). Approximately $80 \%$ of birds that failed the previous year engage in another breeding attempt the following year. All wandering albatrosses had been ringed and sexed as part of a long-term mark recapture program (Weimerskirch et al. 1997), with nestlings being ringed since 1965. In December, pre-breeding adults are counted over the whole island. From mid-January to mid-February, nest contents were checked every ten days to determine the identity of the breeding pairs and breeding status (egg laid/egg hatched) of each individual. In mid-April, June and August, all nests are checked to monitor the survival of chicks.

In the present work, sampled wandering albatrosses were grouped per sex according to their breeding history and age: (i) immatures refer to young birds (3-11 years) that never bred, and (ii) adult albatrosses were those that bred at least once. From 21 December 2007 to 04 March 2008, body feathers were collected on 201 immature and adult wandering albatrosses. Since $\mathrm{Hg}$ is mostly excreted in growing feathers, $\mathrm{Hg}$ level in feathers is considered to be a reliable measure of $\mathrm{Hg}$ bioaccumulation since the last moult (Furness et al. 1986). In wandering albatrosses, feather replacement takes place exclusively during the non-breeding period (Weimerskirch, 1991). Once collected, body feathers were stored dry in individual plastic bags.

\subsection{Hg and stable isotope analyses}

Four body feathers per individual were pooled to obtain a mean isotopic value and an average of $\mathrm{Hg}$ level for body feathers (Bond and Diamond, 2008; Jaeger et al., 2014, Carravieri et al., 2014a). Prior to chemical analysis, feathers were cleaned to remove surface contaminants using a 2:1 chloroform:methanol solution followed by two successive methanol rinses. After cleaning, body feathers were oven dried for $48 \mathrm{~h}$ at $50^{\circ} \mathrm{C}$. Total $\mathrm{Hg}$ was measured at the 
laboratory Littoral Environnement et Sociétés (LIENSs) with an Advanced Mercury Analyzer spectrophotometer (Altec AMA 254). At least two aliquots ranging from 5 to $10 \mathrm{mg}$ dry weight (dw) were analyzed for each individual and measurement quality was certified by reference material, as described by Bustamante et al. (2006). Accuracy was checked using a Certified Reference Material (CRM), Tort-2 Lobster Hepatopancreas, NRC, Canada; certified Hg concentration: $0.27 \pm 0.06 \mu \mathrm{g} \mathrm{g}^{-1}$ dry mass. Mass of the CRM was adjusted to represent the same amount of $\mathrm{Hg}$ introduced in the AMA compared to the one in the feathers. Recovery was $98 \pm 4 \%$ proving good repeatability and reliability of the method. Blanks were analysed at the beginning of each set of samples and the detection limit of the method was $0.005 \mu \mathrm{g} \mathrm{g}^{-1}$ dry mass. Hg concentrations are presented in $\mu \mathrm{g} \mathrm{g}^{-1}$ dry mass.

To test potential effect of foraging habitat and trophic position on feather $\mathrm{Hg}$ levels, the isotopic niche was used as a proxy of the trophic niche (Newsome et al., 2007). The isotopic method was validated in the southern Indian Ocean, with $\delta^{13} \mathrm{C}$ values of seabirds indicating their foraging habitats (Cherel and Hobson, 2007; Jaeger et al., 2010) and their $\delta^{15} \mathrm{~N}$ values increasing with trophic level (Cherel et al., 2010). Feather is a metabolically inactive tissue that reflects the diet at the time it was grown, because keratin is inert after synthesis (Hobson and Clark, 1992; Bearhop et al., 2002). Cleaned pooled feathers (see above) were finely grounded with steel scissors and $0.30 \pm 0.05 \mathrm{mg}$ subsamples of the resulting powder were weighed in tin cups. Isotopic analyses were performed at the laboratory LIENSs with a Thermo Scientific Delta V Advantage mass spectrometer coupled to a Thermo Scientific Flash EA1112 elemental analyser. Results are presented in the usual $\delta$ notation relative to the deviation from international standards (Vienna PeeDee Belemnite and atmospheric $\mathrm{N}_{2}$ for $\delta^{13} \mathrm{C}$ and $\delta^{15} \mathrm{~N}$, respectively). Replicate measurements of internal laboratory standards (acetanilide) indicate measurements errors $<0.10 \%$ for both $\delta^{13} \mathrm{C}$ and $\delta^{15} \mathrm{~N}$ values. 


\subsection{Statistical analyses}

Statistical tests were performed using R 2.15.1 (R Core Team, 2012). A significance level of $\alpha<0.05$ was used for all tests, both in unifactorial and multifactorial analyses. Values are means \pm SD. The effects of intrinsic (age, sex, reproductive status the previous year, 2007) and extrinsic (feeding ecology) factors on $\mathrm{Hg}$ concentrations in feathers were tested using Generalized Linear Models (GLM). Data exploration was carried out following Zuur et al. (2009). Multifactorial analyses were used to test multiple alternative hypotheses on the influence of age, sex, reproductive status, foraging habitat $\left(\delta^{13} \mathrm{C}\right)$ and trophic level $\left(\delta^{15} \mathrm{~N}\right)$ on feather $\mathrm{Hg}$ concentrations. Continuous variables that were significantly correlated were not included in multifactorial models. Notably, feather $\delta^{13} \mathrm{C}$ and $\delta^{15} \mathrm{~N}$ values were strongly correlated (Pearson correlation, $r=0.80, p<0.0001, \mathrm{~N}=201$ ) due to the slight baseline latitudinal enrichment in $\delta^{15} \mathrm{~N}$ values from cold to warm waters of the southern Indian Ocean (Jaeger et al. 2010). GLM with a gamma distribution and an inverse-link function were constructed as follows: $\mathrm{Hg}$ concentrations as the response variable, sex and reproductive status as a categorical explanatory variables and age and feather $\delta^{13} \mathrm{C}$ values as continuous explanatory variables. The models were restricted to primary effects and two-way interactions. Immature birds were considered separately from the adults as they showed a different age-related variation in feather $\mathrm{Hg}$ concentrations. In both cases (immatures and adults), model selection was based on Akaïke's Information Criteria adjusted for small sample sizes (AIC $\mathrm{C}_{\mathrm{c}}$. The model with the lowest $\mathrm{AIC}_{\mathrm{c}}$ value was considered to be the most accurate. Models with AICc values differing by less than two have a similar level of support in the data. Since our aim was to make inference on the variables affecting contaminant burdens, the effect of variables was inferred through Akaike's weights $\left(w_{i}\right)$, and without using model averaging (Burnham and Anderson, 2002). Model fit was checked by residual analysis. 
The effects of $\mathrm{Hg}$ (log-transformed) on breeding probability at the year of sampling (thereafter 2008) and during the last breeding attempt preceding the year of sampling (thereafter in 2005, 2006 or 2007) were tested on sexually-mature albatrosses, using GLM binomial error distribution and a logit link function. Breeding probability was coded as 1 if a bird was observed as a breeder (i.e. incubating an egg or raising a chick) and as 0 if a bird was observed as a nonbreeder at the colony. Finally, we tested whether breeding success during the year of sampling (2008) or during the last breeding attempt preceding the year of sampling $(2005,2006$ or 2007) were linked to feather $\mathrm{Hg}$ levels in individuals sampled as breeders (incubating or chickrearing), by using GLMs with binomial error distribution and a logit link function. Breeding success was coded as 1 for birds that successfully fledged a chick, and as 0 for those that failed at the egg or chick stage. Models were then checked for assumptions that are constancy of variance and residual normality.

The effects of $\mathrm{Hg}$ on long-term demographic parameters were evaluated using the capture-recapture data of sampled sexually-mature albatrosses from 2008 to 2012. A multistage mark-recapture (MSMR) model as developed by Pardo et al. (2013a,b) was built. This model includes eight states: dead, failed breeder on egg (FBE, defined as an individual that was observed with one egg that failed to hatch), failed breeder on chick (FBC, defined as an individual that was observed with one chick but that failed to fledge the chick), successful breeder ( $\mathrm{SB}$, defined as an individual that fledged one chick), observable non-breeder (ONB, defined as an individual that was observed at the colony but that was not observed with an egg or a chick), and three unobservable states (UNB) consisting of non-breeders that were observed at the colony during the previous breeding attempt (PONB), non-breeders whose previous breeding attempt failed (PFB) and non-breeders whose previous breeding attempt was successful (PSB). The state dead $(\dagger)$ was an absorbing state representing death or permanent emigration from the study area. The unobservable states account for temporary absence 
corresponding to birds that skip breeding after breeding unsuccessfully or successfully. States occupied are not directly observed; rather at each occasion $t$, an event happens and is recorded leading to an observed encounter history. In our case, we thus considered five events; $0=$ " $n$ not observed", 1 = "seen as a failed breeder on egg", 2 = "seen as a failed breeder on chick", 3 $=$ "seen as a successful breeder', 4 = “'seen as a non-breeder', which were used to build capture histories. Events and states are considered as random variables, and it is assumed that an event at occasion t depends only on an underlying state (which is not observed) of the individual at the moment, and that successive states follow a Markov chain. Models were parameterized in terms of the probability of survival $(s)$, the probability to return at the colony given survival $(r)$, the probability of breeding given return at the colony $(\beta)$, the probability of successful hatching given breeding $(\omega)$, the probability of successful fledgling given hatching $(\gamma)$, and the detection probability $(p)$. Transition probabilities between states were thus modelled with a five-step procedure where $s, r, \beta, \omega$ and $\gamma$ were considered as five successive steps in transition matrices. Parameters of the model are defined in Table 1. We chose a MSMR approach since this allows taking into account the probability of detecting individuals given their return to the study site. It also allows taking into account the previous breeding state of individuals which might be important to obtain unbiased estimates of demographic parameters (Lebreton and Pradel, 2002).

This MSMR model was parameterized by the survival-transition probabilities matrix:

$\begin{array}{lllllll}\text { FBE } & \text { FBC } & \text { SB } & \text { ONB } & \text { PFB } & \text { PSB } & \text { PONB }\end{array}$

\begin{tabular}{|c|c|c|c|c|c|c|c|}
\hline FBE & {$[\operatorname{sr} \beta(1-\omega)$} & $\operatorname{sr} \beta \omega(1-\gamma)$ & $\operatorname{sr} \beta \omega \gamma$ & $\operatorname{sr}(1-\beta)$ & $s(1-r)$ & - & - \\
\hline FBC & $\operatorname{sr} \beta(1-\omega)$ & $\operatorname{sr} \beta \omega(1-\gamma)$ & $\operatorname{sr} \beta \omega \gamma$ & $\operatorname{sr}(1-\beta)$ & $s(1-r)$ & - & - \\
\hline SB & $\operatorname{sr} \beta(1-\omega)$ & $\operatorname{sr} \beta \omega(1-\gamma)$ & $\operatorname{sr} \beta \omega \gamma$ & $\operatorname{sr}(1-\beta)$ & - & $s(1-r)$ & - \\
\hline ONB & $\operatorname{sr} \beta(1-\omega)$ & $\operatorname{sr} \beta \omega(1-\gamma)$ & $\operatorname{sr} \beta \omega \gamma$ & $\operatorname{sr}(1-\beta)$ & - & - & $s(1-r)$ \\
\hline PFB & $\operatorname{sr} \beta(1-\omega)$ & $\operatorname{sr} \beta \omega(1-\gamma)$ & $\operatorname{sr} \beta \omega \gamma$ & $\operatorname{sr}(1-\beta)$ & - & - & - \\
\hline $\begin{array}{l}\text { PSB } \\
\text { PON }\end{array}$ & $\operatorname{sr} \beta(1-\omega)$ & $\operatorname{sr} \beta \omega(1-\gamma)$ & $\operatorname{sr} \beta \omega \gamma$ & $\operatorname{sr}(1-\beta)$ & - & - & - \\
\hline $\mathrm{B}$ & $\operatorname{sr} \beta(1-\omega)$ & $\operatorname{sr} \beta \omega(1-\gamma)$ & $\operatorname{sr} \beta \omega \gamma$ & $\operatorname{sr}(1-\beta)$ & - & - & - \\
\hline 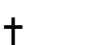 & L $\quad-$ & - & - & - & - & - & - \\
\hline
\end{tabular}

Asterisks $\left(^{*}\right)$ in the column for dead birds $(\dagger)$ represent the complementary parameter (complement of the sum of positive row entries). 
Models' construction and constraints on parameters were exactly the same than those previously detailed in a paper about the demographic consequences of blood $\mathrm{Hg}$ levels in the wandering albatross (Goutte et al. 2014b). We tested for an effect of $\mathrm{Hg}$ on demographic parameters to test the hypothesis that feather $\mathrm{Hg}$ levels in one breeding season may influence the long-term survival and breeding outputs of an individual over the following years. The $95 \%$ confidence interval of the slope parameters and AICc was used for inference. The goodness-offit (GOF) of the time-dependent MSMR model was tested using U-CARE (Choquet et al., 2009a). Model selection was based on $\mathrm{AIC}_{\mathrm{c}}$ and all models were run under program E-SURGE 1.8.5 allowing splitting transition probabilities between states (Choquet et al., 2009b). To avoid estimating parameters at a local minimum of the likelihood function, each model was run five times with random initial values.

\section{Results}

\subsection{Influence of biological and environmental factors on $\mathrm{Hg}$ bioaccumulation}

Overall, feather $\mathrm{Hg}$ concentrations of wandering albatrosses averaged $24 \pm 12 \mu \mathrm{g} \mathrm{g}^{-1}$ and showed a wide range of values, from 6 to $95 \mu \mathrm{g} \mathrm{g}^{-1}$ (Table 2), with the latter value being considered an outlier. Univariate multifactorial analyses were performed to estimate the influence of sex, age, reproductive status, and feeding habitat $\left(\delta^{13} \mathrm{C}\right)$ on $\mathrm{Hg}$ concentrations in feathers of immature and adult birds separately, because feather $\mathrm{Hg}$ concentration was higher in immatures than in adults (32 \pm 15 versus $22 \pm 10 \mu \mathrm{g} \mathrm{g}^{-1}$; Table 2 ). For immature and adult albatrosses, multiple models had a similar support, and explained at best $17 \%$ and $23 \%$ of the total variation, respectively (Table 3). In immatures, age was clearly the most influential variable, with sex having also a relatively high explanatory power as shown by the sum of Akaike's weights across 
all models (Table 3). Feather Hg concentrations decreased with age in immature birds (Fig. 1a) and were overall lower in males than females (26 \pm 14 and $37 \pm 15 \mu \mathrm{g} \mathrm{g}^{-1}$, respectively; Table 2).

The effect of sex on feather $\mathrm{Hg}$ concentrations was much stronger in adults than immature wandering albatrosses. In contrast to immature birds, age had no significant influence on feather $\mathrm{Hg}$ concentrations of adult albatrosses (Fig. 1b). Instead, the sum of Akaike's weights across all models showed that feather $\delta^{13} \mathrm{C}$ values and sex were the most influential variables on adult feather $\mathrm{Hg}$ concentrations (Table 3). Specifically, $\mathrm{Hg}$ concentrations were positively related to $\delta^{13} \mathrm{C}$ values (Fig. 2a) and were significantly lower in males than in females $(19 \pm 10$ vs. $26 \pm 9 \mu \mathrm{g} \mathrm{g}^{-1}$, respectively; Table 2 , Fig. 2). $\mathrm{Hg}$ concentrations were also positively related to $\delta^{15} \mathrm{~N}$ values (Fig 2b), given the strong correlation between feather $\delta^{13} \mathrm{C}$ and $\delta^{15} \mathrm{~N}$ values (see Materials and Methods).

\subsection{Effects of Hg on current breeding output}

The probability of breeding during the last breeding attempt (between 2005 and 2007) and during the 2008 season was not linked to $\mathrm{Hg}$ concentrations in feathers (last breeding attempt: $\mathrm{df}=1,159, \chi^{2}=1.742, \mathrm{p}=0.189 ; 2008: \mathrm{df}=1,165, \chi^{2}=0.288, \mathrm{p}=0.592$ ). When considering only breeders, current breeding success was not related to $\mathrm{Hg}$ levels in feathers (last breeding attempt: $\left.\mathrm{df}=1,118, \chi^{2}=2.105, \mathrm{p}=0.147 ; 2008: \mathrm{df}=1,129, \chi^{2}=1.849, \mathrm{p}=0.174\right)$.

\subsection{Long-term fitness consequences of $\mathrm{Hg}$ exposure}

The GOF of the MSMR model was overall not significant (males: $\chi^{2}=25.186$, d.f. $=25, p=$ 0.452 and females: $\chi^{2}=7.094$, d.f. $\left.=25, \mathrm{p}=1.000\right)$. Model 5 and model 14 had lower AICc than the intercept model (Table 4) suggesting that $\mathrm{Hg}$ in feathers were negatively related to return rate of individuals previously in state SB and positively related to breeding probability of males previously in states FBE or FBC. However, $\triangle \mathrm{AICc}$ values with the intercept model 
were less than 2 (1.61 and 0.5) and the confidence intervals of estimated slope included 0 (Table 4). Therefore it must be considered that there was no effect of feather $\mathrm{Hg}$ levels on any demographic parameters.

\section{Discussion}

The present study benefits from the long-term demographic investigation (from 1965 onward) on wandering albatrosses from Possession Island, resulting in the unique sampling of $>200$ birds of known sex, age and breeding status during the same summer season. Together with previous investigations on blood $\mathrm{Hg}$ using the same individual birds (Carravieri et al., 2014b; Goutte et al., 2014b), this study is one of the most comprehensive evaluations of $\mathrm{Hg}$ levels, with its explanatory factors and demographic consequences, in free-living animals of known life-history traits. The previous studies considered blood $\mathrm{Hg}$ that represents the shortterm exposure of the birds, while the present work focused on feather $\mathrm{Hg}$ that represents the long-term exposure. Accumulated $\mathrm{Hg}$ since the last moult is excreted into the feathers, which represent more than one year exposure in the case of the wandering albatross.

\subsection{Comparison to other populations and species}

Average feather $\mathrm{Hg}$ concentration of wandering albatrosses from Possession Island (24

$\left.\mu \mathrm{g} \mathrm{g}^{-1}\right)$ is within the range of values obtained in other localities from the southern Indian Ocean (Marion: $25 \mu \mathrm{g} \mathrm{g}^{-1}$, Kerguelen: $17 \mu \mathrm{g} \mathrm{g}^{-1}$; Thompson et al., 1993; Carravieri et al. 2014c) and southern Atlantic Ocean (South Georgia: 20-27 $\mu \mathrm{g} \mathrm{g}^{-1}$; Thompson et al., 1993; Anderson et al., 2009; Tavares et al., 2013). This suggests that $\mathrm{Hg}$ has a fairly similar bioavailability within these different sectors of the Southern Ocean, which is in agreement with its circumpolar annular (latitudinal) oceanographic structure (Sokolov and Rintoul 2007). The observed feather $\mathrm{Hg}$ levels in the wandering albatross confirm that large albatrosses (Family Diomedeidae; 
Thompson et al., 1993), together with some other Procellariiformes (Procellariidae and Hydrobatidae; Monteiro et al., 1999; Carravieri et al. 2014c) are amongst the most $\mathrm{Hg}$ contaminated seabird species overall (mean values $>10 \mu \mathrm{g} \mathrm{g}^{-1}$ ) (authors' unpublished review).

Body feather $\mathrm{Hg}$ concentrations of wandering albatrosses from Possession Island varied with a 16 magnification factor among individuals, with one 23 years-old male showing the remarkably high feather concentration of $95 \mu \mathrm{g} \mathrm{g}^{-1}$ (Table 2). To the best of our knowledge, this value is the highest ever recorded in body feathers for any bird in the current open scientific literature, followed by the levels of one common loon Gavia immer (76 $\mu \mathrm{g} \mathrm{g}^{-1}$; Evers et al.,

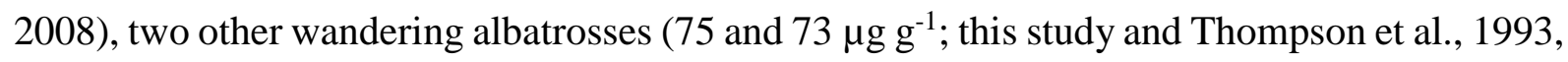
respectively) and one common tern chick Sterna hirundo from a highly-polluted area (70 $\mu \mathrm{g} \mathrm{g}^{-}$

${ }^{1}$; Furness et al. 1995). Noticeably, these values are well above the commonest used toxicity threshold (5 $\mu \mathrm{g} \mathrm{g}^{-1}$; Burger and Gochfeld, 1997) and above the adverse effect threshold for adult loons $\left(40 \mu \mathrm{g} \mathrm{g}^{-1}\right)$, the best studied species in the wild up to date (Evers et al., 2008). Together with the highest $\mathrm{Hg}$ concentration reported in the liver of any bird species $\left(1800 \mu \mathrm{g} \mathrm{g}^{-1} \mathrm{dw}\right.$; Hindell et al., 1999), the wandering albatross and probably related species of the Genus Diomedea, appear to be thus good model animals to investigate the detoxification mechanisms allowing to cope with such high $\mathrm{Hg}$ body burdens.

\subsection{Explanatory factors}

Interestingly, feather $\mathrm{Hg}$ concentrations of wandering albatrosses were only influenced by age in immature birds (pre-breeders) and no effect of this factor was detected in individuals over 12 years-old. The lack of age-dependent variation in $\mathrm{Hg}$ concentrations has already been reported for known-age seabirds both in blood of e.g. wandering albatrosses (Tavares et al 2013; Carravieri et al. 2014b), and in feathers of e.g. red-billed gulls Larus novaehollandiae and great 
skuas Catharacta skua (Furness et al. 1990; Thompson et al. 1991), with also some possible decreasing trends being observed as in adult snow petrels (Tartu et al. 2014). Our finding for immature wandering albatrosses is consistent with the results of Tavares et al. (2013) who reported an increase of $\mathrm{Hg}$ concentrations between chicks and immature albatrosses returning for the first time to the colony (age ranging from 4 to 6 years) and then a decline to a lower constant average value in breeding adults. Although no chicks were sampled in the present study, it is noteworthy that wandering albatross chicks from South Georgia and Kerguelen Islands had similar Hg levels, ranging between 2 to $10 \mu \mathrm{g} \mathrm{g}^{-1}$ (Becker et al. 2002; Blévin et al. 2013, Tavares et al. 2013). These Hg levels represent the assimilated metal accumulated during chick growth over months that was ultimately excreted in newly grown feathers at the end of the period (Lewis and Furness 1991).The subsequent $\mathrm{Hg}$ bioaccumulation in fledged young albatrosses up to their first reproduction would therefore reflect elevated exposure to the metal. The higher feather $\mathrm{Hg}$ concentrations in immatures than in adults would firstly be due to a difference in the foraging areas exploited by the two age classes. Indeed, taking into account latitudinal changes in $\delta^{13} \mathrm{C}$ in the southern Indian Ocean (Jaeger et al., 2010), lower $\delta^{13} \mathrm{C}$ values in the feathers of adult individuals show that they forage in more southern waters compared to immatures during the inter-breeding period (Table 2). Because of the temporal uncoupling of $\mathrm{Hg}$ (representing exposure during the whole inter-moult period) and stable isotopes (representing food assimilated during feather synthesis) in feathers, the use of stable isotopes to interpret $\mathrm{Hg}$ concentrations in this tissue has to be done cautiously (Bond, 2010). Nevertheless, adult individuals foraging at higher latitudes (subantarctic waters) had lower $\mathrm{Hg}$ concentrations compared to those foraging in the northern subtropics (Fig. 2). As immatures feed all year round in subtropical waters (Jaeger et al. 2014; Weimerskirch et al 2014), they should be exposed to higher quantity of $\mathrm{Hg}$ compared to adults that forage at higher latitudes at least during the reproduction period. 
Higher $\mathrm{Hg}$ concentrations in the feathers of immature rather than adult wandering albatrosses were attributed to differences in moulting patterns (Tavares et al., 2013). Indeed, immatures show greater difficulties in replacing their feathers because they are less experienced to find and catch their prey compared to breeders (Weimerskirch, 1991). If a nutritional deficit occurs, it might reduce the capacity of immature albatrosses to synthetize new feathers. The decreasing $\mathrm{Hg}$ levels with increasing age in immature birds corroborate this hypothesis, likely reflecting (i) the change in foraging behaviour (shift to more southern habitats) and (ii) the progressive establishment of a regular moult. Feather $\mathrm{Hg}$ concentrations reflect blood $\mathrm{Hg}$ concentrations at the time of moult (Bearhop et al. 2000; Evers et al. 2008). Feather $\mathrm{Hg}$ concentrations are therefore dependent of both (i) the exposure at the time of their synthesis (dietary $\mathrm{Hg}$ ), and (ii) the release of $\mathrm{Hg}$ accumulated since the last moulting event (Furness et al., 1986; Thompson et al., 1998). Therefore, moult appears as a crucial mechanism of $\mathrm{Hg}$ detoxification in birds. If moult occurs at a lower frequency in immatures compared to adults, feather $\mathrm{Hg}$ concentrations should be higher in immatures. On the other hand, demethylation of $\mathrm{Hg}$ and its subsequent co-precipitation with $\mathrm{Se}$ in the liver of Procellariiforms appears to constitute a significant detoxification strategy (Nigro and Leonzio 1996; Thompson and Furness, 1989b; Thompson et al. 1993), which leads to extremely high concentrations of accumulated Hg in this organ (e.g. Muirhead and Furness 1988; Stewart et al., 1999; Hindell et al. 1999). It is possible that such a detoxification process is not yet fully efficient in young albatrosses, making feathers the major pathway of detoxification for this age class, whereas it may allow at maintaining almost constant the quantity of $\mathrm{Hg}$ subsequently excreted in feathers of adults.

In adult albatrosses, $\mathrm{Hg}$ concentrations were higher in females than in males showing that maternal transfer of $\mathrm{Hg}$ to the egg seems limited in the wandering albatross. Data for stable isotopes in both feathers (present study) and blood (Carravieri et al. 2014b) rather suggest that 
such a gender difference is related to sexual segregation in foraging areas and hence diets. Male wandering albatrosses mainly forage in subantarctic waters during the breeding period, whereas they moult in subtropical waters outside the breeding period (Weimerskirch et al 2014; Jaeger et al., 2014). On the other hand, females rely essentially on subtropical waters throughout their life, visiting also subantarctic waters during incubation (Weimerskirch et al 2014). On average, females thus forage at more northern latitudes than males (Jaeger et al., 2014). Wandering albatrosses prey predominantly upon large squids, both at northern and southern latitudes (Cherel and Weimerskirch 1999). Cephalopods mainly bioaccumulate Hg under its methylated form (MeHg), which is thus highly bioavailable for their consumers (Bustamante et al. 2006). Even if information on $\mathrm{Hg}$ concentrations in the prey of the wandering albatross is missing over its wide-range foraging area, it is likely that cephalopods from subtropical waters had higher $\mathrm{Hg}$ concentrations than those from the subantarctic area as it is the case in Kerguelen Island waters (Bustamante et al. 2003; unpublished data). This would reduce the Hg bioaccumulation of adult males when compared to females, at least during the breeding period, as shown by blood Hg analyses (Carravieri et al., 2014b). This pattern has already been reported for other seabird species from the Kerguelen Islands, with species foraging predominantly within the limits of the Southern Ocean year-round (e.g. the light-mantled albatross Phoebetria palpebrata) having lower $\mathrm{Hg}$ concentrations than those foraging in northern subtropical and neritic waters (Carravieri et al. 2014c). In this context, the wandering albatross appears as a valuable species to document latitudinal variations in $\mathrm{Hg}$ transfer in their food web.

\subsection{Demographic consequences of long-term Hg exposure}

Few studies have explored the demographic consequences of $\mathrm{Hg}$ on wild aquatic birds, with a main focus on short-term exposure using blood Hg (e.g. Evers et al. 2008; Burgess and Meyers 2008; Goutte et al. 2014a, b, 2015). Using a long-term data set and MSMR models, the 
present study is among the first to explore the effects of feather $\mathrm{Hg}$ on current breeding output, long-term fecundity and survival in seabirds. Even if $\mathrm{Hg}$ concentrations in body feathers were extremely high, no effect on neither breeding probability, hatching and fledgling successes, nor adult survival was detected. This finding contrasts strongly with results obtained with blood that highlighted a negative impact of $\mathrm{Hg}$ on long-term breeding, hatching and fledging probabilities in the wandering albatross (Goutte et al. 2014b). Contrary to previous studies on blood Hg (e.g. Brasso and Cristol, 2008; Frederick and Jayasena, 2010; Tartu et al., 2013, 2014, 2015), no negative effect of feathers $\mathrm{Hg}$ was detected on the breeding probability and the breeding success at the year of sampling. These results deserve further investigations as one can expect that the integrated $\mathrm{Hg}$ would have stronger effect on reproduction than blood $\mathrm{Hg}$ concentrations during the reproductive period.

Although $\mathrm{Hg}$ in feathers is considered to be an integrative measure of total $\mathrm{Hg}$ body burden (Furness et al., 1986), our analyses did not detect any strong correlation between $\mathrm{Hg}$ in feathers and long-term reproductive outputs. As commented previously, feathers replacement in wandering albatross takes more than a year (Weimerskirch, 1991), leading to $\mathrm{Hg}$ bioaccumulation in the liver (see above). Hence, $\mathrm{Hg}$ in feathers would reflect different exposure periods of wandering albatrosses according to the analysed feathers. In contrast, blood reflects dietary contaminants exposure during the energetically challenging breeding period, and $\mathrm{Hg}$ in blood appears to be more critical for long-term reproductive responses (Goutte et al. 2014ab).

Estimated demographic parameters were similar to those previously estimated in the same population of wandering albatrosses, using all ringed individuals (Pardo et al. 2013a; Barbraud and Weimerskirch, 2012). Despite high $\mathrm{Hg}$ concentrations in the feathers which revealed an elevated exposure to $\mathrm{Hg}$ since the previous moult (Carravieri et al. 2014a), the survival rate of wandering albatrosses was not jeopardized by $\mathrm{Hg}$. This is consistent with previous studies that did not detect an effect of $\mathrm{Hg}$ on adult mortality in free-living birds (Mitro 
et al., 2008; Wayland et al., 2008; Hallinger et al., 2011; Goutte et al., 2014a, b, 2015). However, our study did not exclude that $\mathrm{Hg}$ could jeopardize the survival rate of immature wandering albatrosses, since they had higher Hg concentrations (Tavares et al., 2013), and lower survival rate (Weimerskirch et al. 1997) than sexually-mature adults.

\section{Conclusion}

The wandering albatrosses from Crozet Islands displayed remarkably elevated $\mathrm{Hg}$ concentrations in their feathers as a consequence of their high trophic position. $\mathrm{Hg}$ concentrations are the highest in immatures and, after birds start reproduction, they remained stable in adults. Both a different moulting frequency and detoxification processes could be responsible for such differences between maturity stages. In both immatures and adults, females had higher $\mathrm{Hg}$ concentrations as they forage at lower latitude on prey that are likely enriched in Hg compared to higher latitude prey. Despite elevated Hg concentrations in their feathers reflecting long-term exposure to the metal, no effect on the demographic parameters were evidenced suggesting that long-term bioaccumulated $\mathrm{Hg}$ was not under a form leading to deleterious effects.

\section{Acknowledgements}

The authors warmly thank: A. Jaeger and V. Lecomte for collecting samples; H. Maheo, M. Berlincourt and all the wintering fieldworkers involved in the long-term monitoring programs for their help in the field; C. Churlaud and M. Brault-Favrou from the Plateforme Analyses Elémentaires (LIENSs) and G. Guillou from the Plateforme Analyses Isotopiques (LIENSs) for their help in the analyses; D. Besson for managing the long-term data base. This study was supported financially and logistically by the Poitou-Charentes Region through a PhD grant to 
A. Carravieri, by the Agence Nationale de la Recherche (ANR PolarTop, O. Chastel), by the French Polar Institute (IPEV, program 109, H. Weimerskirch), by the Terres Australes et Antarctiques Françaises, the Zone Atelier de Recherches sur l'Environnement Antarctique et Subantarctique (CNRS-INEE) and by the CPER 13 (Contrat de Projet Etat-Région). Field procedures were authorized by the Ethics Committee of IPEV and by the Comite de l'Environnement Polaire.

\section{References}

Anderson ORJ, Phillips RA, McDonald RA, Shore RF, McGill RAR, Bearhop S (2009) Influence of trophic position and foraging range on mercury levels within a seabird community. Mar. Ecol. Prog. Ser. 375: 277288.

Barbraud C, Weimerskirch H (2012) Estimating survival and reproduction in a quasi-biennially breeding seabird with uncertain and unobservable states. J. Ornithol. 152: 605-615.

Bearhop S, Ruxton GD, Furness RW (2000) Dynamics of mercury in blood and feathers of great skuas. Environ. Toxicol. Chem. 19: 1638-1643.

Bearhop S, Waldron S, Votier SC, Furness RW (2002) Factors that influence assimilation rates and fractionation of nitrogen and carbon stable isotopes in avian blood and feathers. Physiol. Biochem. Zool.75: 451-458.

Becker PH, González-Solís J, Behrends B, Croxall J (2002) Feather mercury levels in seabirds at South Georgia: influence of trophic position, sex and age. Mar. Ecol. Prog. Ser. 243: 261-269.

Blévin P, Carravieri A, Jaeger A, Chastel O, Bustamante P, Cherel Y (2013) Wide range of mercury contamination in chicks of Southern Ocean seabirds. Plos One, 8(1): e54508.

Bloom NS (1992) On the chemical form of mercury in edible fish and marine invertebrate tissue. Canad. J. Fish. Aquat. Sci. 49: 1010-1016.

Bond AL, Diamond AW (2008) High within-individual variation in total mercury concentration in seabird feathers. Environm. Toxicol. Chem. 27: 2375-2377.

Bond AL (2010) Relationships between stable isotopes and metal contaminants in feathers are spurious and biologically uninformative. Environ. Pollut. 158: 1182-1184.

Brasso RL, Cristol DA (2008) Effects of mercury exposure on reproductive success of tree swallows (Tachycineta bicolor). Ecotoxicology, 17: 133-141.

Brasso RL, Drummond BE, Borrett SR, Chiaradia A, Polito MJ, Rey AR (2013) Unique pattern of molt leads to low intraindividual variation in feather mercury concentrations in penguins. Environ. Toxicol. Chem. 32: 2331-2334.

Braune BM, Gaskin DE (1987) Mercury levels in Bonaparte's gulls (Larus philadelphia) during autumn moult in the Quoddy region, New Brunswick, Canada. Arch. Environ. Contam. Toxicol. 16: 539-549.

Burger J, Gochfeld M (1997) Risk, mercury levels, and birds: relating adverse laboratory effects to field biomonitoring. Environ. Res. 75: 160-72. 
Burgess NM, Meyer MW (2008) Methylmercury exposure associated with reduced productivity in common loons. Ecotoxicology 17: doi: 10.1007/s10646-007-0167-8

Burnham KP, Anderson DR (2002) Model selection and multi-model inference: a practical information theoretic approach. Second Edition; Springer, New York.

Bustamante P, Bocher P, Cherel Y, Miramand P, Caurant F (2003) Distribution of trace elements in the tissues of benthic and pelagic fish from the Kerguelen Islands. Sci. Tot. Environ. 313: 25-39.

Bustamante P, Lahaye V, Durnez C, Churlaud C, Caurant F (2006) Total and organic Hg concentrations in cephalopods from the North East Atlantic waters: influence of geographical origin and feeding ecology. Sci. Tot. Environ. 368: 585-596.

Carravieri A, Bustamante P, Churlaud C, Cherel Y (2013) Penguins as bioindicators of mercury contamination in the Southern Ocean: Birds from the Kerguelen Islands as a case study. Sci. Tot. Environ. 454-455: 141-148.

Carravieri A, Bustamante P, Churlaud C, Fromant A, Cherel Y (2014a) Moulting patterns drive within-individual variations of stable isotopes and mercury in seabird body feathers: implications for monitoring of the marine environment. Mar. Biol. 161(4): 963-968.

Carravieri A, Bustamante P, Tartu S, Meillère A, Labadie P, Budzinski H, Peluhet L, Barbraud C, Weimerskirch H, Chastel O, Cherel Y (2014b). Wandering Albatrosses Document Latitudinal Variations in the Transfer of Persistent Organic Pollutants and Mercury to Southern Ocean Predators. Environ. Sci. Technol. 48: 1474614755.

Carravieri A, Cherel Y, Blévin P, Brault-Favrou M, Chastel O, Bustamante P (2014c) Mercury exposure in a large subantarctic avian community. Environ. Pollut. 190C: 51-57.

Cherel Y, Fontaine C, Richard P, Labat JP (2010) Isotopic niches and trophic levels of myctophid fishes and their predators in the Southern Ocean. Limnol. Oceanogr. 55: 324-332.

Cherel Y, Hobson KA (2007) Geographical variation in carbon stable isotope signatures of marine predators: a tool to investigate their foraging areas in the Southern Ocean. Mar. Ecol. Prog. Ser. 329: 281-287.

Cherel Y, Weimerskirch H (1999) Spawning cycle of onychoteuthid squids in the southern Indian Ocean: new information from seabird predators. Mar. Ecol. Prog. Ser. 188: 93-104.

Choquet R, Lebreton JD, Gimenez O, Reboulet AM, Pradel R (2009a) U-CARE: Utilities for performing goodness of fit tests and manipulating CApture-REcapture data. Ecography. 32: 1071-1074.

Choquet R, Rouan L, Pradel R (2009b) Program E-SURGE: a software application for fitting multievent models. In: Thomson DL, Cooch EG, Conroy MJ (eds) Modeling demographic processes in marked populations. Springer, New York, pp 845-865.

Cuvin-Aralar A, Furness RW (1991) Mercury and selenium interaction: a review. Ecotox. Environ. Saf. 21: 348364.

Das K, Debacker V, Bouquegneau JM (2000) Metallothioneins in marine mammals. Cell. Mol. Biol. 46: 283-294.

Delord K, Besson D, Barbraud C, Weimerskirch H (2008) Population trends in a community of large Procellariiforms of Indian Ocean: Potential effects of environment and fisheries interactions. Biol. Cons. 141: 1840-1856.

Evans HL, Garman RH, Laties VG (1982) Neurotoxicity of methylmercury in the pigeon. Neurotoxicology 3: 2136. 
Evers DC, Savoy LJ, DeSorbo CR, Yates DE, Hanson W, Taylor KM, Siegel LS, Cooley JH, Bank MS, Major A (2008) Adverse effects from environmental mercury loads on breeding common loons. Ecotoxicology 17: 6981.

Frederick P, Jayasena N (2010) Altered pairing behaviour and reproductive success in white ibises exposed to environmentally relevant concentrations of methylmercury. Proc. R. Soc. B 278: 1851-1857.

Furness RW, Muirhead SJ, Woodburn M (1986) Using bird feathers to measure mercury in the environment: relationship between mercury content and moult. Mar. Pollut. Bull. 17: 27-37.

Furness RW, Lewis SA, Mills JA (1990) Mercury levels in the plumage of red-billed gulls Larus novaehollandiae scopulinus of known sex and age. Environ. Pollut. 63: 33-39.

Furness RW, Thompson DR, Becker PH (1995) Spatial and temporal variation in mercury contamination of seabirds in the North Sea. Helgölander Meeres. 49: 605-615.

Goutte A, Bustamante P, Barbraud C, Delord K, Weimerskirch H, Chastel O (2014a) Demographic responses to mercury exposure in two closely related Antarctic top predators. Ecology 95: 1075-1086.

Goutte A, Barbraud C, Meillère A, Carravieri A, Bustamante P, Labadie P, Budzinski H, Delord K, Cherel Y, Weimeskirch H, Chastel O (2014b) Demographic consequences of heavy metals and persistent organic pollutants in a vulnerable long-lived bird, the wandering albatross. Proc. Roy. Soc. B, 281: 20133313.

Goutte A, Barbraud C, Herzke D, Bustamante P, Angelier F, Tartu S, Clément-Chastel C, Moe B, Bech C, Gabrielsen GW, Bustnes JO, Chastel O (2015) Survival rate and breeding outputs in a high Arctic seabird exposed to legacy persistent organic pollutants and mercury. Environ. Pollut. 200C: 1-9.

Hallinger KK, Cornell KL, Brasso RL, Cristol DA (2011) Mercury exposure and survival in free-living tree swallows (Tachycineta bicolor). Ecotoxicology. 20: 39-46.

Hindell MA, Brothers N, Gales R (1999) Mercury and cadmium concentrations in the tissues of three species of southern albatrosses. Polar Biol. 22: 102-108.

Hobson KA, Clark RG (1992) Assessing avian diets using stable isotopes I: turnover of ${ }^{13} \mathrm{C}$ in tissues. Condor 94 : $181-188$

Jaeger A, Lecomte VJ, Weimerskirch H, Richard P, Cherel Y (2010) Seabird satellite tracking validates the use of latitudinal isoscapes to depict predators' foraging areas in the Southern Ocean. Rapid Comm. Mass Spectr. 24: $3456-3460$

Jaeger A, Goutte A, Lecomte VJ, Richard P, Chastel O, Barbraud C, Weimerskirch H, Cherel Y (2014) Age, sex, and breeding status shape a complex foraging pattern in an extremely long-lived seabird. Ecology 95: 23242333.

Koeman JH, Peeters WHM, Koudstaal-Hol CHM, Tjioe PS, De Goeij JJM (1973) Mercury-selenium correlations in marine mammals. Nature 245: 385-386.

Lebreton J-D, Pradel R. 2002 Multistate recapture models: modelling incomplete individual histories. J. Appl. Stat. 29: 353-369.

Lewis SA, Furness RW (1991) Mercury accumulation and excretion in laboratory reared black-headed gull Larus ridibundus chicks. Arch. Environ. Contam. Toxicol. 21: 316-320.

Martoja R, Berry JP (1980) Identification of tiemannite as a probable product of demethylation of mercury by selenium in cetaceans. A complement to the scheme of the biological cycle of mercury. Vie Milieu 30: 7-10. 
Mitro MG, Evers DC, Meyer MW, Piper WH (2008) Common loon survival rates and mercury in New England and Wisconsin. J. Wildlife Manag. 72: 665-673.

Monteiro LR, Furness RW (1995) Seabirds as monitors of mercury in the marine environment. Water Air Soil Pollut. 80(1-4): 851-870.

Monteiro LR, Granadeiro JP, Furness RW, Oliveira P (1999) Contemporary patterns of mercury contamination in the Portuguese Atlantic inferred from mercury concentrations in seabird tissues. Mar. Environ. Res. 47: 137156.

Muirhead SJ, Furness RW (1988) Heavy metal concentrations in the tissues of seabirds from Gough Island, South Atlantic Ocean. Mar. Pollut. Bull. 19: 278-283

Newsome SD, Martinez del Rio C, Bearhop S, Phillips DL (2007) A niche for isotopic ecology. Frontiers Ecol. Environ. 5: 429-436.

Nigro M, Leonzio C (1996) Intracellular storage of mercury and selenium in different marine vertebrates. Mar. Ecol. Prog. Ser. 135: 137-143.

Nriagu JO (1996) A history of global metal pollution. Science 272: 223-224.

Pardo D, Weimerskirch H, Barbraud C (2013a) When celibacy matters: incorporating non-breeders improves demographic parameter estimates. PLoS ONE 8: e60389.

Pardo D, Weimerskirch H, Barbraud C (2013b) Females better face senescence in the wandering albatross. Oecologia 173: 1283-1294.

R Core Team (2012) R: A language and environment for statistical computing. R Foundation for Statistical Computing, Vienna, Austria. ISBN 3-900051-07-0, URL http://www.R-project.org/

Sokolov S, Rintoul SR (2007) On the relationship between fronts of the Antarctic circumpolar current and surface chlorophyll concentrations in the Southern Ocean. J. Geophys. Res. 112, C07030.

Stewart FM, Phillips RA, Bartle JA, Craig J, Shooter D (1999) Influence of phylogeny, diet, moult schedule and sex on heavy metal concentrations in New Zealand Procellariiformes. Mar. Ecol. Prog. Ser. 178: 295-305.

Tan SW, Meiller JC, Mahaffey KR (2009) The endocrine effects of mercury in humans and wildlife. Crit. Rev. Toxicol. 39: 228-269.

Tartu S, Goutte A, Bustamante P, Angelier F, Moe B, Clément-Chastel C, Bech C, Gabrielsen GW, Bustness JO, Chastel O (2013) To breed or not to breed: endocrine response to mercury contamination by an arctic seabird. Biol. Letters 9(4): 20130317.

Tartu S, Bustamante P, Goutte A, Cherel Y, Weimeskirch H, Bustness JO, Chastel O (2014) Age-related mercury contamination and relationship with luteinizing hormone in a long-lived Antarctic bird. Plos One 9(7): e103642.

Tartu S, Angelier F, Wingfield JC, Bustamante P, Labadie P, Budzinski H, Weimerskirch H, Bustnes JO, Chastel $\mathrm{O}$ (2015) Corticosterone, prolactin and egg neglect behaviour in relation to mercury and legacy POPs in a longlived Antarctic bird. Sci. Tot. Environ. 505C: 180-188.

Tartu S, Bustamante P, Angelier F, Lendvai AZ, Moe B, Blévin P, Bech C, Gabrielsen GW, Bustnes JO, Chastel O (2015) Mercury exposure, stress and prolactin secretion in an Arctic seabird: an experimental study. Funct. Ecol. DOI: 10.1111/1365-2435.12534

Tavares S, Xavier JC, Phillips RA, Pereira ME, Pardal MA (2013) Influence of age, sex and breeding status on mercury accumulation patterns in the wandering albatross Diomedea exulans. Environ. Pollut. 181: 315-320. 
Thompson DR, Furness RW (1989a) Comparison of the levels of total and organic mercury in seabird feathers. Mar. Pollut. Bull. 20: 557-79.

Thompson DR, Furness RW (1989b) The chemical form of mercury stored in South Atlantic seabirds. Environ. Pollut. 60: 305-17.

Thompson DR, Hamer KC, Furness RW (1991) Mercury accumulation in great skuas Catharacta skua of known age and sex, and its effects upon breeding and survival. J. Appl. Ecol. 28: 672-684.

Thompson DR, Furness RW, Lewis SA (1993) Temporal and spatial variation in mercury concentrations in some albatrosses and petrels from the sub-Antarctic. Polar Biol. 13: 239-244.

Thompson DR, Furness RW, Monteiro LR (1998) Seabirds as biomonitors of mercury inputs to epipelagic and mesopelagic marine food chains. Sci. Tot. Environ. 213: 299-305.

Wagemann R, Trebacz E, Boila G, Lockhart WL (1998) Methylmercury and total mercury in tissues of arctic marine mammals. Sci. Tot. Environ. 218: 19-31.

Wagemann R, Trebacz E, Boila G, Lockhart WL (2000) Mercury species in the liver of ringed seals. Sci. Tot. Environ. 261: 21-32.

Wayland M, Drake KL, Alisauskas RT, Kellett DK, Traylor J, Swoboda C, Mehl K (2008) Survival rates and blood metal concentrations in two species of free-ranging North American sea ducks. Environ. Toxicol. Chem. 27: 698-704.

Weimerskirch H (1991) Sex-specific differences in molt strategy in relation to breeding in the Wandering albatross. Condor 93: 731-737.

Weimerskirch H, Brothers N, Jouventin P (1997) Population dynamics of wandering albatross Diomedea exulans and Amsterdam albatross D. amsterdamensis in the Indian Ocean and their relationships with long-line fisheries: conservation implications. Biol. Conserv. 79: 257-270.

Weimerskirch H, Cherel Y, Delord K, Jaeger A, Patrick SC, Riotte-Lambert L (2014) Lifetime foraging patterns of the wandering albatross: life on the move. J. Exp Mar. Biol. Ecol. 450: 68-78

Zuur AF, Ieno EN, Walker N, Saveliev AA, Smith GM (2009) Mixed Effects Models and Extensions in Ecology with R. Springer. 529p.DOI:10.1007/978-0-387-87458-6 


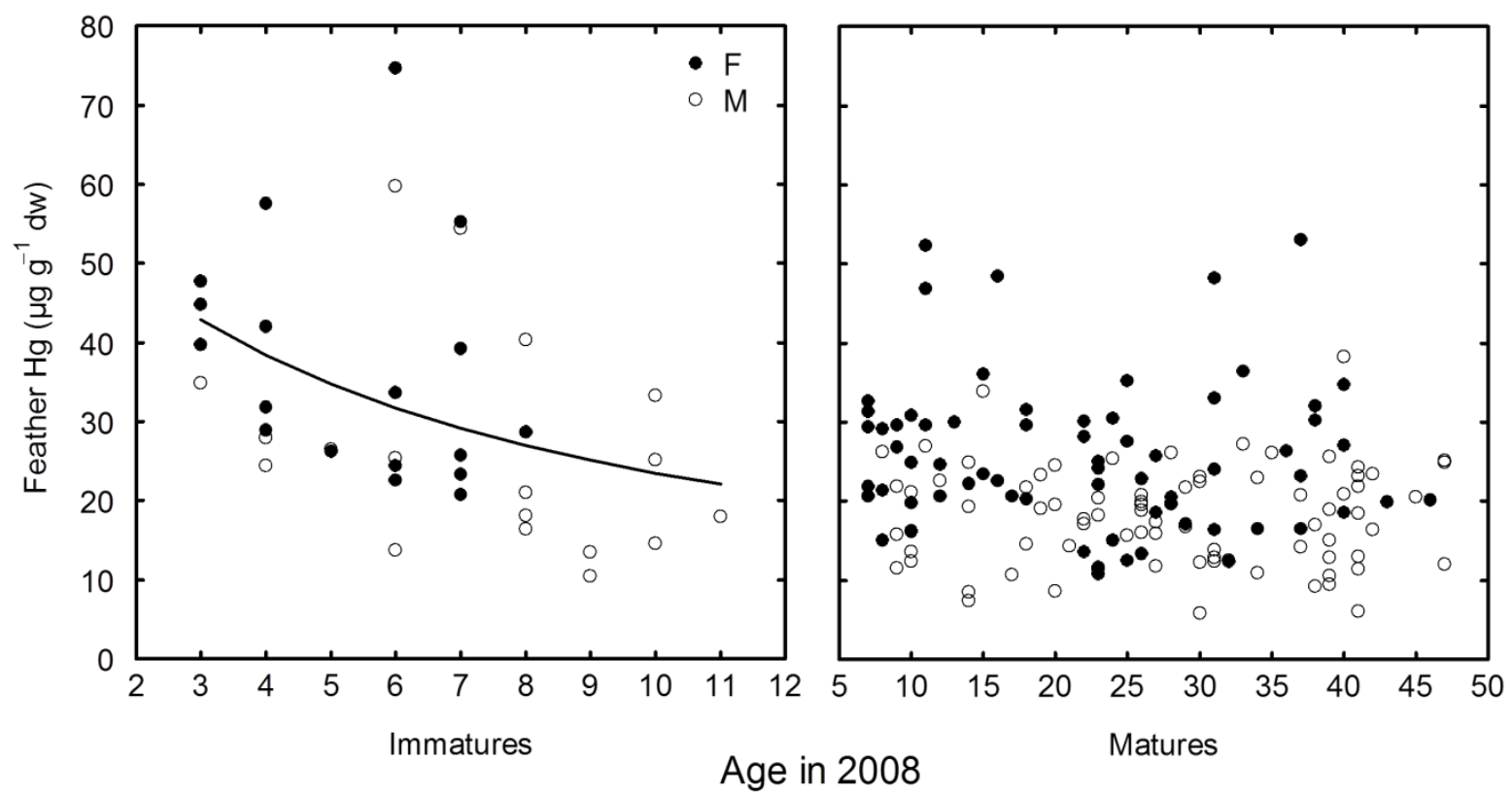

Fig. 1. Hg concentrations $\left(\mu \mathrm{g} \mathrm{g}^{-1} \mathrm{dw}\right)$ in body feathers of immature and adult wandering albatrosses from Possession Island as a function of age. F: females; M: males; continuous line: GLM (gamma distribution, inverse link function: immature feather $\mathrm{Hg}=$ age). 

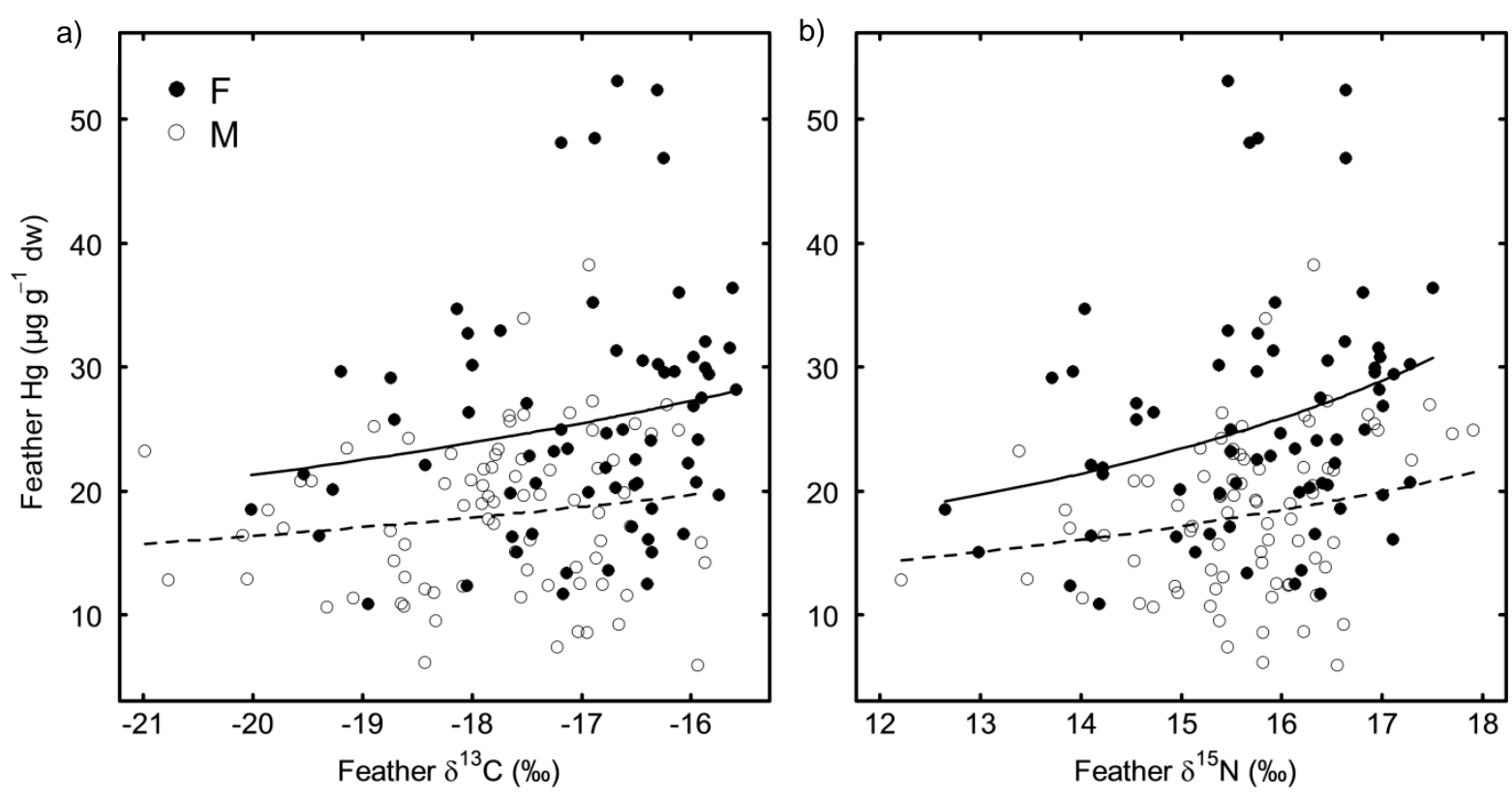

Fig. 2. $\mathrm{Hg}$ concentrations $\left(\mu \mathrm{g} \mathrm{g}^{-1} \mathrm{dw}\right)$ in body feathers of adult wandering albatrosses from Possession Island as a function of a) feather $\delta^{13} \mathrm{C}$ and b) feather $\delta^{15} \mathrm{~N}$. F: females; M: males; continuous and dotted lines for females and males, respectively: GLM (gamma distribution, inverse link function: feather $\mathrm{Hg}=\delta^{13} \mathrm{C}+$ sex and feather $\mathrm{Hg}=\delta^{15} \mathrm{~N}+\operatorname{sex}$ ). 
Table 1. Definition of parameters used in the multistate mark-recapture model

\begin{tabular}{|l|l|}
\hline Parameter & Definition \\
\hline$s_{s}^{t}$ & $\begin{array}{l}\text { Probability that an individual in state } s \text { at time } t \text { survives to time } t+1 \text { and does not } \\
\text { permanently emigrate from the study area }\end{array}$ \\
\hline$r_{s}^{t}$ & $\begin{array}{l}\text { Probability that an individual in state } s \text { at time } t \text { returns at the colony to time } t+1 \\
\text { given that it survives to } t+1\end{array}$ \\
\hline$\beta_{s}^{t}$ & $\begin{array}{l}\text { Probability that an individual in state } s \text { at time } t \text { breeds at time } t+1 \text { given that it } \\
\text { survives to and returns at the colony at time } t+1\end{array}$ \\
\hline$\gamma_{s}^{t}$ & $\begin{array}{l}\text { Probability that an individual in state } s \text { at time } t \text { incubates successfully at time } t+1 \\
\text { given that it survives to, returns at the colony and breeds at time } t+1\end{array}$ \\
\hline$\delta_{s}^{t}$ & $\begin{array}{l}\text { Probability that an individual in state } s \text { at time } t \text { raises successfully one chick at time } t \\
+1 \text { given that it survives to, returns at the colony and incubates successfully at time } t \\
+1\end{array}$ \\
\hline$p_{s}^{t}$ & Probability that an individual in state $s$ at time t is encountered at time $t+1$ \\
\hline
\end{tabular}


Table 2. Hg concentrations $\left(\mu \mathrm{g} \mathrm{g}^{-1} \mathrm{dw}\right)$ and stable isotope values in body feathers of the wandering albatross from Possession Island (F: females; M: males).

\begin{tabular}{|c|c|c|c|c|c|c|c|c|}
\hline & \multirow[t]{2}{*}{$\mathrm{N}$} & \multicolumn{2}{|c|}{$\mathrm{Hg}$} & \multicolumn{3}{|c|}{$\delta^{13} \mathrm{C}$} & \multicolumn{2}{|c|}{$\delta^{15} \mathrm{~N}$} \\
\hline & & Mean \pm SD & Min-Max & Mean \pm SD & Min-Max & & Mean \pm SD & Min-Max \\
\hline All & 201 & $23.87 \pm 11.83$ & $5.86-94.72$ & $-17.32 \pm 1.12$ & $-20.99-$ & - & $15.79 \pm 0.99$ & $12.21-17.91$ \\
\hline $\mathrm{F}$ & 91 & $28.00 \pm 11.33$ & $10.85-74.72$ & $-16.94 \pm 1.03$ & $-20.02-$ & - & $15.87 \pm 1.04$ & $12.65-17.51$ \\
\hline M & 110 & $20.44 \pm 11.17$ & $5.86-94.72$ & $-17.64 \pm 1.09$ & -20.99 & - & $15.73 \pm 0.94$ & $12.21-17.91$ \\
\hline Immatures & 36 & $31.80 \pm 14.96$ & $10.4-74.72$ & $-16.77 \pm 0.84$ & $-18.65-$ & - & $16.13 \pm 0.71$ & $14.65-17.48$ \\
\hline$F$ & 18 & $37.06 \pm 14.60$ & $20.76-74.72$ & $-16.54 \pm 0.90$ & $-18.65-$ & - & $16.17 \pm 0.82$ & $14.65-17.48$ \\
\hline M & 18 & $26.53 \pm 13.74$ & $10.4-59.69$ & $-16.99 \pm 0.76$ & $-18.13-$ & - & $16.08 \pm 0.61$ & $15.13-17.17$ \\
\hline Adults & 165 & $22.14 \pm 10.30$ & $5.86-94.72$ & $-17.44 \pm 1.13$ & $-20.99-$ & - & $15.72 \pm 1.02$ & $12.21-17.91$ \\
\hline $\mathrm{F}$ & 73 & $25.77 \pm 9.20$ & $10.85-53.11$ & $-17.04 \pm 1.04$ & $-20.02-$ & - & $15.79 \pm 1.08$ & $12.65-17.51$ \\
\hline M & 92 & $19.25 \pm 10.26$ & $5.86-94.72$ & $-17.76 \pm 1.10$ & -20.99 & - & $15.66 \pm 0.98$ & $12.21-17.91$ \\
\hline \multicolumn{9}{|l|}{ Age classes } \\
\hline $3-12$ & 67 & $28.67 \pm 12.96$ & $10.40-74.72$ & $-16.85 \pm 0.86$ & $-19.54-$ & - & $16.04 \pm 0.83$ & $13.71-17.48$ \\
\hline $13-25$ & 53 & $23.40 \pm 12.83$ & 7.39-94.72 & $-17.13 \pm 0.91$ & $-19.20-$ & - & $15.94 \pm 0.94$ & $12.98-17.70$ \\
\hline 26-35 & 43 & $19.54 \pm 7.90$ & $5.86-48.15$ & $-17.54 \pm 1.10$ & $-20.77-$ & - & $15.67 \pm 1.03$ & $12.21-17.51$ \\
\hline$>35$ & 38 & $20.95 \pm 9.08$ & $6.08-53.11$ & $-18.18 \pm 1.28$ & $-20.99--15.87$ & & $15.31 \pm 1.09$ & $12.65-17.91$ \\
\hline
\end{tabular}


Table 3. Model selection for $\mathrm{Hg}$ concentrations in feathers of immature and adult wandering albatrosses from Possession Island. Models are sorted by increasing $\triangle \mathrm{AIC}_{\mathrm{c}}$ (i.e., decreasing model fit). Abbreviations: AICc: Akaike's Information Criteria adjusted for small sample-sizes; Exp. var.: explained variation of the model; wi: Akaike's weights; $\Sigma w_{i}$ Sum of Akaike's weights across all models of each tested explanatory variable.

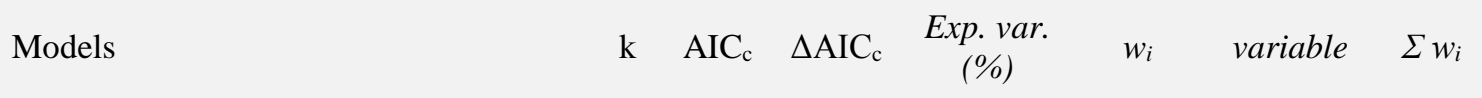

Immatures - GLM (gamma distribution, inverse link function), n= 36 (M: 18, F: 18)

$\begin{array}{lrrrrrrr}\text { Age } & 2 & 288 & 0.00 & 15 & 0.324 & \text { Age } & 0.80 \\ \text { Age }+ \text { Sex } & 3 & 289 & 0.45 & 17 & 0.258 & \text { Sex } & 0.58 \\ \text { Sex } & 2 & 290 & 1.66 & 11 & 0.142 & \delta^{13} \mathrm{C} & 0.17 \\ \delta^{13} \mathrm{C}+\text { Age }+ \text { Sex } & 4 & 291 & 2.56 & 16 & 0.090 & & \\ \text { Age }+ \text { Sex }+ \text { Age:Sex } & 4 & 291 & 3.05 & 15 & 0.070 & & \\ \delta^{13} \mathrm{C}+\text { Age }+\delta^{13} \mathrm{C}: \text { Age } & 4 & 292 & 3.57 & 14 & 0.054 & & \\ \text { Null } & 1 & 293 & 4.62 & 0 & 0.032 & \\ \delta^{13} \mathrm{C}+\text { Sex }+\delta^{13} \mathrm{C}: \text { Sex } & 4 & 294 & 5.96 & 8 & 0.016 & \\ \delta^{13} \mathrm{C} & 2 & 295 & 6.50 & 0 & 0.013 & \end{array}$

Adults - GLM (gamma distribution, inverse link function), n = 165 (M: 92, F: 73)

\begin{tabular}{|c|c|c|c|c|c|c|c|}
\hline$\delta^{13} \mathrm{C}+$ Age + Sex + Status + Age:Status & 8 & 1002 & 0.00 & 23 & 0.350 & Age & 0.61 \\
\hline$\delta^{13} \mathrm{C}+\operatorname{Sex}$ & 3 & 1003 & 1.10 & 20 & 0.201 & Sex & 0.99 \\
\hline $\begin{array}{l}\delta^{13} \mathrm{C}+\text { Age }+ \text { Sex }+ \text { Status }+\delta^{13} \mathrm{C}: \operatorname{Sex}+ \\
\text { Age: } \text { Status }\end{array}$ & 9 & 1004 & 2.29 & 23 & 0.111 & Status & 0.62 \\
\hline$\delta^{13} \mathrm{C}+$ Sex + Status & 5 & 1005 & 2.54 & 20 & 0.098 & $\delta^{13} \mathrm{C}$ & 0.87 \\
\hline Sex & 2 & 1005 & 3.05 & 18 & 0.076 & & \\
\hline$\delta^{13} \mathrm{C}+$ Age + Sex & 4 & 1005 & 3.23 & 19 & 0.070 & & \\
\hline $\begin{array}{l}\delta^{13} \mathrm{C}+\text { Age }+ \text { Sex }+ \text { Status }+\delta^{13} \mathrm{C}: \text { Age } \\
+\delta^{13} \mathrm{C}: \text { Sex }+ \text { Age: } \text { Status }\end{array}$ & 10 & 1007 & 4.61 & 22 & 0.035 & & \\
\hline Age + Sex & 3 & 1007 & 4.96 & 18 & 0.029 & & \\
\hline Sex + Status & 4 & 1008 & 5.88 & 18 & 0.018 & & \\
\hline Age + Sex + Status & 5 & 1010 & 7.77 & 17 & 0.007 & & \\
\hline $\begin{array}{l}\delta^{13} \mathrm{C}+\text { Age }+ \text { Sex }+ \text { Status }+\delta^{13} \mathrm{C}: \text { Age } \\
+\delta^{13} \mathrm{C}: \text { Sex }+\delta^{13} \mathrm{C}: \text { Status }+ \text { Age:Status }\end{array}$ & 12 & 1011 & 9.01 & 21 & 0.004 & & \\
\hline$\delta^{13} \mathrm{C}$ & 2 & 1023 & 21.19 & 8 & 0.00 & & \\
\hline$\delta^{13} \mathrm{C}+$ Status & 4 & 1023 & 21.35 & 9 & 0.00 & & \\
\hline$\delta^{13} \mathrm{C}+\mathrm{Age}$ & 3 & 1025 & 22.99 & 7 & 0.00 & & \\
\hline$\delta^{13} \mathrm{C}+$ Age + Status & 5 & 1025 & 23.03 & 9 & 0.00 & & \\
\hline Age & 2 & 1033 & 30.92 & 2 & 0.00 & & \\
\hline Age + Status & 4 & 1034 & 32.26 & 2 & 0.00 & & \\
\hline Null & 1 & 1034 & 32.26 & 0 & 0.00 & & \\
\hline Status & 3 & 1036 & 34.28 & 0 & 0.00 & & \\
\hline
\end{tabular}


Table 4. Modelling the effects of standardized $\mathrm{Hg}$ levels in feathers on demographic parameters $(\mathrm{N}=167$ individuals). The estimated slope and $95 \%$ confidence intervals (CI) for models with a lower AICc than the intercept model (0) are given.

\begin{tabular}{|c|c|c|c|c|c|c|}
\hline Hypothesis & Model & Rank & Deviance & $\triangle \mathrm{AICc}$ & Slope & {$[\mathrm{CI}-; \mathrm{CI}+]$} \\
\hline Effect of $\mathrm{Hg}$ on return rate of individuals previously in state SB & 14 & 24 & 1632.73 & 0 & -0.38 & {$[-0.76 ; 0.01]$} \\
\hline Effect of $\mathrm{Hg}$ on breeding probability of males previously in states FBE or FBC & 5 & 24 & 1633.84 & 1.11 & 1.31 & {$[-0.37 ; 2.99]$} \\
\hline Intercept model: no effect of $\mathrm{Hg}$ on demographic parameters & 0 & 23 & 1636.55 & 1.61 & & \\
\hline Effect of $\mathrm{Hg}$ on breeding probability of females previously in state ONB & 10 & 24 & 1634.66 & 1.93 & & \\
\hline Effect of $\mathrm{Hg}$ on breeding probability of females previously in state SB & 8 & 24 & 1634.67 & 1.95 & & \\
\hline Effect of $\mathrm{Hg}$ on fledgling success of individuals previously in states ONB or UNB & 2 & 24 & 1635.45 & 2.72 & & \\
\hline Effect of $\mathrm{Hg}$ on breeding probability of males previously in state ONB & 9 & 24 & 1635.76 & 3.04 & & \\
\hline Effect of $\mathrm{Hg}$ on breeding probability of females previously in states $\mathrm{PFB}$, PSB or PONB & 12 & 24 & 1635.88 & 3.15 & & \\
\hline Effect of $\mathrm{Hg}$ on fledgling success of individuals previously in states FB and SB & 1 & 24 & 1636.03 & 3.30 & & \\
\hline Effect of $\mathrm{Hg}$ on survival rate of males & 16 & 24 & 1636.17 & 3.44 & & \\
\hline Effect of $\mathrm{Hg}$ on breeding probability of males previously in states PFB, PSB or PONB & 11 & 24 & 1636.31 & 3.58 & & \\
\hline Effect of $\mathrm{Hg}$ on survival rate of females & 17 & 24 & 1636.52 & 3.79 & & \\
\hline Effect of $\mathrm{Hg}$ on breeding probability of females previously in states FBE or FBC & 6 & 24 & 1636.54 & 3.89 & & \\
\hline Effect of $\mathrm{Hg}$ on hatching success of individuals previously in states FB and SB & 3 & 24 & 1636.55 & 3.90 & & \\
\hline Effect of $\mathrm{Hg}$ on breeding probability of males previously in state SB & 7 & 24 & 1636.55 & 3.82 & & \\
\hline Effect of $\mathrm{Hg}$ on hatching success of individuals previously in states ONB or UNB & 4 & 24 & 1636.55 & 3.82 & & \\
\hline Effect of $\mathrm{Hg}$ on return rate of individuals previously in states ONB, PFB, PSB or PONB & 15 & 24 & 1636.55 & 3.82 & & \\
\hline Effect of $\mathrm{Hg}$ on return rate of individuals previously in states FBE or FBC & 13 & 24 & 1636.55 & 3.82 & & \\
\hline
\end{tabular}

